Erratum

\title{
Erratum: Zalameda, J. et al. Detection and Characterization of Damage in Quasi-Static Loaded Composite Structures using Passive Thermography. Sensors 2018, 18, 3562
}

\author{
Joseph Zalameda * and William Winfree \\ NASA Langley Research Center, MS231 Hampton, VA 23681, USA; william.p.winfree@nasa.gov \\ * Correspondence: joseph.n.zalameda@nasa.gov; Tel.: +1-757-864-4793
}

Received: 8 November 2018; Accepted: 11 November 2018; Published: 15 November 2018

The authors wish to correct Table 1 in their paper published in Sensors [1], doi:10.3390/s18103562, https: / / www.mdpi.com/1424-8220/18/10/3562. The following corrected table should be used with incorrect references removed from original. The corrected table does not change the scientific results. The correct references are used in the original manuscript. The manuscript will be updated and the original will remain online on the article web page, with a reference to this Erratum.

Table 1. Model values.

\begin{tabular}{cc}
\hline Model Variable & Value \\
\hline$l$ (thickness of flange + skin) & $0.46 \mathrm{~cm}$ \\
Instantaneous Heat Flux & 1.0 Watt $/ \mathrm{cm}^{2}$ \\
Flaw Position & 4.3 to $6.3 \mathrm{~cm}$ \\
$L$ (Slab Width) & $10.2 \mathrm{~cm}$ \\
$\alpha_{\mathrm{z}}$ (through thickness thermal diffusivity) & $0.0042 \mathrm{~cm}^{2} / \mathrm{s}$ \\
$\alpha_{\mathrm{x}}$ (lateral thermal diffusivity) & $0.021 \mathrm{~cm}^{2} / \mathrm{s}$ \\
$K$ (thermal conductivity) & $0.0045 \mathrm{~W} / \mathrm{cm} / \mathrm{K}$ \\
$N$ (Discrete positions in $x$ ) & 160 \\
\hline
\end{tabular}

\section{Reference}

1. Zalameda, J.; Winfree, W. Detection and Characterization of Damage in Quasi-Static Loaded Composite Structures using Passive Thermography. Sensors 2018, 18, 3562. [CrossRef] [PubMed]

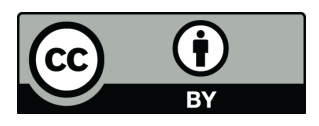

(C) 2018 by the authors. Licensee MDPI, Basel, Switzerland. This article is an open access article distributed under the terms and conditions of the Creative Commons Attribution (CC BY) license (http://creativecommons.org/licenses/by/4.0/). 